\title{
The ichthyofauna of upper rio Capivari: defining conservation strategies based on the composition and distribution of fish species
}

\author{
Paulo dos Santos Pompeu ${ }^{1}$, Liana Sisi dos Reis ${ }^{1}$, Cíntia Veloso Gandini ${ }^{1}$, \\ Rafael Couto Rosa de Souza ${ }^{1}$ and Jana Menegassi del Favero ${ }^{2}$
}

\begin{abstract}
Although the rio Capivari basin is recognized as an area of great importance for the ichthyofauna, it lacks virtually every basic requirement for the definition of appropriate conservation strategies, since not even its species composition is known. The objective of this work is to determine the composition and distribution of fish species in the upper rio Capivari basin, relating them to the local physical features, and to evaluate the effectiveness of proposed conservations units, delimited based on areas of native vegetation remains, on the conservation of local ichthyofauna. During 2007, 50 different watercourses were sampled with gillnets, cast nets and kick nets. A total of 1308 individuals belonging to 41 species were captured. Degree of conservation, altitude and width were the parameters that best explained fish species richness. Considering the recently proposed boundaries for potential conservation units in the region only 15 or 20 out of 41 species would be found in the State Park and Environmental Protection Area respectively. In practice, the proposed conservation units would not be effective tools for fish conservation, since it would be located in mountainous areas of high altitude, of headwaters streams and where few species are found. In such context, the conservation of specific stretches of larger rivers is critical.
\end{abstract}

Embora o alto rio Capivari seja reconhecido como área de grande importância para a fauna de peixes, faltam praticamente todos os requisitos básicos para a definição de estratégias de conservação adequadas, já que nem mesmo sua composição em espécies é conhecida. O presente trabalho teve como objetivo geral determinar a composição e distribuição das espécies de peixes do alto rio Capivari e relacioná-las com as características físicas locais. Adicionalmente, avaliou-se a efetividade da implantação de unidades de conservação, que tiveram seus limites propostos com base na presença de remanescentes de vegetação nativa, para a conservação da ictiofauna local. Durante o ano de 2007 foram amostrados 50 diferentes cursos d'água na bacia com redes de emalhar, tarrafas e peneiras. Foram capturados 1308 indivíduos pertencentes a 41 espécies. O grau de conservação, a altitude e a largura foram os parâmetros que melhor explicaram a riqueza de espécies de peixes. Caso os limites de uma futura unidade de conservação fossem baseados nas manchas de vegetação remanescentes, apenas 15 ou 20 das 41 espécies seriam encontradas na área do Parque Estadual ou da Área de Proteção Ambiental, respectivamente. Na prática, as áreas protegidas propostas não constituiriam ferramentas eficazes para a conservação de peixes, principalmente porque se situariam em áreas montanhosas, de grande altitude, abrigando apenas cabeceiras de rios, onde poucas espécies são encontradas. Dentro deste contexto, a conservação de trechos específicos de rios de maior porte é fundamental.

Key words: Conservation units, Altitudinal gradients, Rio Grande, Reserve design.

\section{Introduction}

Throughout history, rivers have provided the foundation for socioeconomic development. Water is used for domestic, industrial, agricultural and power generation purposes; rivers provide navigation routes and fishing is a traditional food resource (Petts, 1989). As a consequence, an increasing number of rivers, streams, lakes and reservoirs have been exposed to degradation as a function of the growing impact of human activities (McAllister et al., 1997).

This picture is particularly noticeable in densely populated areas, where aquatic environments present poor quality as a result of receiving a considerable amount of domestic and industrial sewage as well as sediments and waste. Additionally, the urbanization process causes irreversible changes to the local drainage basin by increasing impermeable areas,

${ }^{1}$ Departamento de Biologia, Universidade Federal de Lavras, Campus Universitário, 37200-000 Lavras, MG, Brazil. pompeu@ufla.br ${ }^{2}$ Programa de Pós-Graduação em Oceanografia Biológica, Instituto Oceanográfico, Universidade de São Paulo. São Paulo, SP, Brazil. 
reducing vegetation coverage, causing soil compaction, reducing storage areas, concentrating surface drainage and stimulating river straightening and channelization. These changes lead to a progressive increase in the precipitation fraction that rapidly goes into watercourses through superficial drainage (Chow et al., 1988), directly affecting the local geomorphology. Direct changes in watercourses also include removal of riparian vegetation, removal of trunks and other submerged substrata, elimination of adjacent flooding areas and artificial lining of riverbeds and riverbanks.

In a direct association with urban growth, rivers have been altered to a point where they lose their natural characteristics (Vieira \& Cunha, 2001), many of which presenting today only a small fraction of their original biological diversity (Shepp \& Cummins, 1997). Particularly noticeable is the loss of fish biodiversity and abundance that has been associated to changes in original lotic characteristics (Sale, 1985) or to disposal of domestic and industrial sewage (Alves \& Pompeu, 2005; Pompeu et al., 2005).

There is a consensus among the scientific community that chances of long-term maintenance of biodiversity will increase significantly with the establishment of a conservation plan to address the issue on a regional scale or encompassing larger landscape units (Conservation International, 2000a), and protected areas are the cornerstone of most national biodiversity conservation strategies, including the Brazil (Mittermeier et al., 2005). In such context, the recognition of areas that maintain rich species diversity or priority areas for conservation constitutes a fundamental tool for protection of biodiversity (Allan \& Flecker, 1993).

The rio Capivari basin has been recognized as one of critical biological importance for conservation of the ichthyofauna in Minas Gerais State (Drummond et al., 2005) as it is an important lotic remainder in the upper rio Grande region and its watercourses boast excellent water quality. Additionally, the rio Capivari basin drains the region of Luminárias, São Tomé das Letras and Carrancas as well as part of the region that houses the Serra da Mantiqueira mountain range, both recognized by the same study for their outstanding and special biological importance. The importance of the region was also recognized by an assessment workshop addressing Priority Actions for Conservation of Biodiversity in the Atlantic Forest and Campos Sulinos biomes (Conservation International, 2000b).

Although the rio Capivari basin is recognized as an area of great importance for the ichthyofauna, it lacks virtually every basic requirement for the definition of appropriate conservation strategies, since not even its species composition is known.

The overall objective of this work is to determine the composition and distribution of fish species in the upper rio Capivari basin, relating them to the local physical features, and to evaluate the effectiveness of an eventual state park, that have been proposed based on areas of native vegetation remnants (Zambaldi et al., in press) on the conservation of local ichthyofauna.

\section{Material and Methods}

\section{Study Area}

The rio Grande has a drainage basin in Minas Gerais State with an approximate area of $86,800 \mathrm{~km}^{2}$ (CETEC, 1983). It extends $1,930 \mathrm{~km}$, with an average slope of $0.53 \mathrm{~m} \mathrm{~km}^{-1}$. Its main tributaries include the rivers Airuoca, Capivari, São João and Carmo, on the left bank, and the rivers Jacaré, das Mortes, Santana, Uberaba and Pouso Alegre, on the right bank. In Minas Gerais, rio Grande is dammed along virtually its entire course, with the hydroelectric power plants of Funil, Itutinga and Camargos the ones lying upstream.

Situated among the Funil and Itutinga reservoirs, the rio Capivari is one of the main tributary on the left bank of rio Grande in Minas Gerais State. Its upper portion drains the regions of Carrancas and Luminárias and has been found increasingly attractive to tourism as it boasts a large number of waterfalls, good water quality and a generalized high level of landscape preservation.

The region is constituted by flat and undulated surfaces, with the ascent of Complexo Serra da Bocaina mountain range deserving special attention, with altitudes reaching between 1,100 and $1,250 \mathrm{~m}$. The high-altitude tropical climate is predominant locally, with average annual temperatures ranging between $19^{\circ} \mathrm{C}$ and $21^{\circ} \mathrm{C}$ and average annual rainfall between 1,200 and 1,500 mm (Queiroz et al., 1980). The dominant vegetal formation is the Cerrado (savanna like vegetation), and rocky landscapes predominate on mountain range tops. Riparian vegetation is also present along the watercourses, and large clusters of mesophyllous forest are present on some steeper hillsides.

The studied area is known as 'Alto Capivari' and comprises the entire drainage basin of rio Capivari, upstream from (and including) its confluence with its main tributary, rio Ingaí. It includes the area previously selected for conservation unit implementation, with a state park in the core area and a surrounding environmental protection area (EPA) as a buffer zone (Fig. 1).

\section{Ichthyofauna sampling}

During 2007, 50 different watercourses were sampled once in upper rio Capivari basin (Fig. 1; Table 1), during April, May, October or November. Fish were caught with gillnets, cast nets ( $3 \mathrm{~cm}$ stretch measure mesh) and kick nets (mesh size of $1 \mathrm{~mm}$ ). Gillnets 10 meters long, with 3 to $10 \mathrm{~cm}$ mesh (stretch measure), were set in the water column for 14 h overnight, in sampling stations with at least 1.5 meters depth. Kick nets were employed in near-shore aquatic macrophytes (both shorelines) and in riffles, and cast nets were used in habitats too deep to wade. The two latter methods were employed during one to three hours. Stretches of 50 to 100 meters were surveyed, depending on depth and water flow.

All samples were separated according to sampling point, stored in plastic bags and immediately fixed in $10 \%$ formalin and preserved in $70 \%$ alcohol. In the laboratory, the fish collected in each sample were identified down to the lowest 


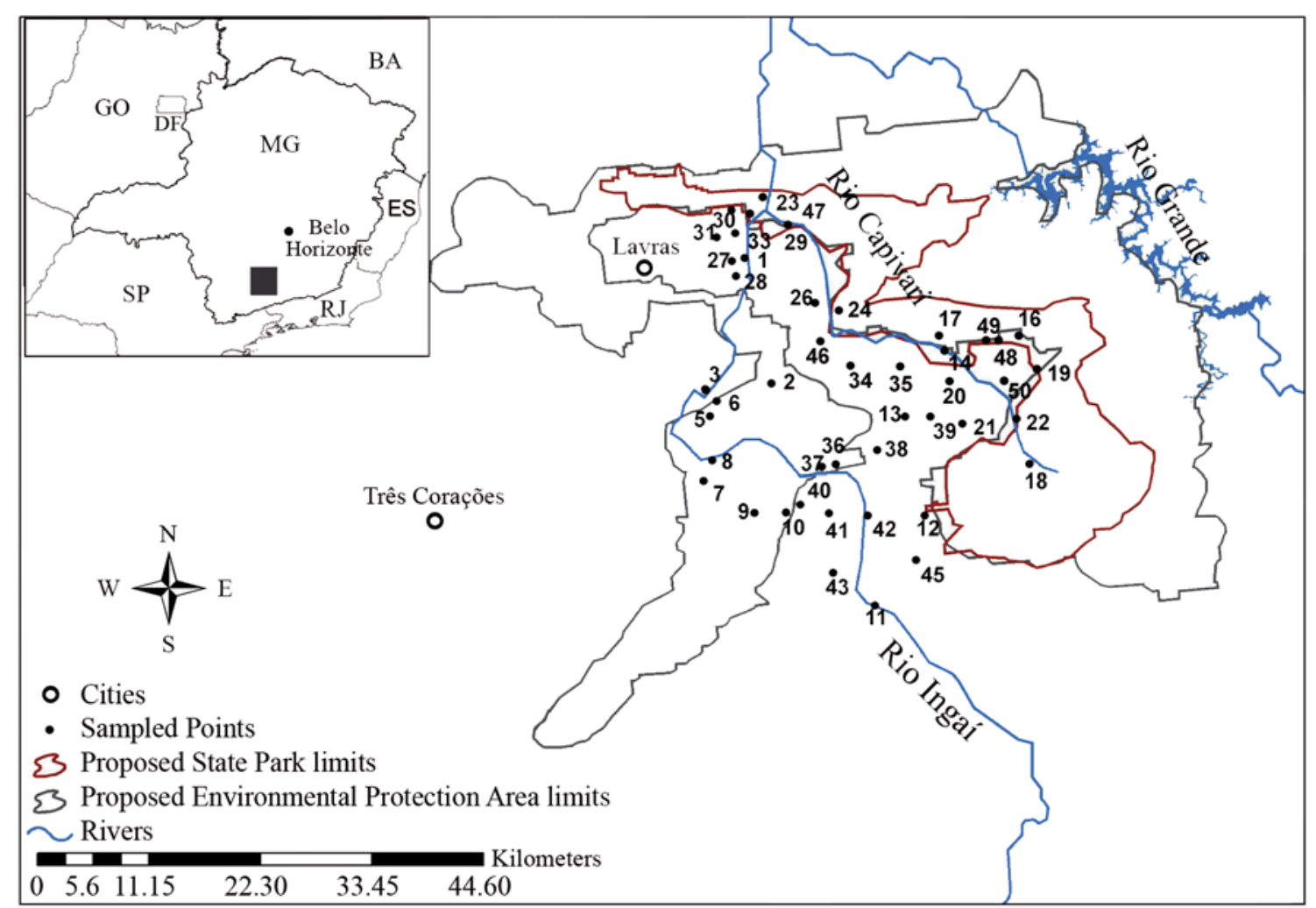

Fig. 1. Map indicating sampling points and proposed boundaries for a State Park and an Environmental Protection Area (EPA) based on Zambaldi et al. (in press).

possible taxonomic level, measured (standard length - SL in $\mathrm{mm}$ ) and weighed (1 g precision). Voucher specimens were deposited in the Ichthyological Collection of Nupelia (NUP voucher numbers from 8551 to 8553 and 8574 to 8611 ).

\section{Habitat assessment}

In each sampled station it was measured the average width, maximum depth, altitude, $\mathrm{pH}$, temperature and dissolved oxygen using digital oxymeter YSI-55. Simultaneously, a quick assessment protocol was performed (Bain \& Stevenson, 1999; Barbour et al., 1999), evaluating nine physical parameters: available cover; embeddedness; velocity/depth regime; sediment deposition; channel flow status; channel alteration; bank stability; vegetative protection and riparian vegetative zone width. Each of these parameters was assessed on a scale from zero to ten, and for each sampled station considered optimal $(\geq 8)$, intermediary $(8>x \geq 4)$ or poor $(<4)$. An overall score was also attributed to each point, considering the summatory of the nine parameters scores, divided by 0.9 , and this was considered as estimation of the stream reach conservation status. Additionally, the order of each sampled watercourse was also determined (Strahler, 1964), based on 1:100.000 maps.

\section{Data analyses}

Species accumulation curve based on the addition of new sampling points, and the estimators of species richness
Jackknife 1 and Chao 1 calculated with the software EstimateS (Colwell, 1997) were used to access the representativeness of the fish diversity sampling in the entire study region. The relationship between the streams evaluated variables (order, width, depth, altitude, and conservation) and the fish richness was tested through multiple regression. Canonical Correspondence Analysis (CCA) was used to evaluate the relationship between the relative abundance of fish species (number of sampled fish by species divided by the total abundance in each location) and the variables that significantly explained the fish richness and the parameters $\mathrm{pH}$, dissolved oxygen and temperature. This analysis was carried out using the software Canoco for Windows 4.0; only species with at least five captured individuals were included.

\section{Results}

The sampling points were situated between 877 and 1,214 meters of altitude, and were in the first to sixth stream order range, presenting width of 1 to 20 meters and maximum depth of 0.5 to 3 meters. Most streams presented high levels of dissolved oxygen (> $5 \mathrm{ppm}$ ), slightly basic $\mathrm{pH}$, water temperature between $15^{\circ} \mathrm{C}$ to $20^{\circ} \mathrm{C}$, and a very good state of conservation (Table 1). The main impacts that were observed were related to sediment deposition and reduced substrata for the fauna (Fig. 2). 
Table 1. Location and characterization of sampling points in upper Capivari basin (Altit. = altitude; $W=$ width; $\mathrm{D}=$ depth; Temp. = temperature; D.O. = dissolved oxygen; $\mathrm{SC}$ = score for state of conservation).

\begin{tabular}{|c|c|c|c|c|c|c|c|c|c|c|c|}
\hline & Location & $\begin{array}{c}\text { UTM } \\
\text { E }\end{array}$ & $\begin{array}{c}\text { UTM } \\
\mathrm{N} \\
\end{array}$ & Order & Altit. (m) & $\mathrm{W}(\mathrm{m})$ & $\mathrm{D}(\mathrm{m})$ & $\mathrm{pH}$ & Temp. $\left({ }^{\circ} \mathrm{C}\right)$ & D.O. (ppm) & SC \\
\hline 1 & rio Ingaí - P1 & 510307 & 7633397 & 6 & 881 & 20 & $>2$ & 5.35 & 19 & 6.41 & 65 \\
\hline 2 & ribeirão da Cachoeira & 512978 & 7620842 & 4 & 937 & 8 & 1.3 & 6.29 & 17.8 & 6.01 & 95 \\
\hline 3 & rio Ingaí - P2 & 506337 & 7620173 & 6 & 906 & 15 & 12 & 6.8 & 19.6 & 6.46 & 90 \\
\hline 4 & rio Ingaí - P3 & 506337 & 7620300 & 6 & 911 & - & $>2$ & 5.72 & 19.7 & 5.78 & - \\
\hline 5 & córrego do Retiro & 506831 & 7617583 & 2 & 968 & 2 & 0.5 & 6.22 & 17.8 & 5.15 & 61 \\
\hline 6 & córrego Mata Boi & 507513 & 7619065 & 4 & 895 & 4 & 1 & 6.47 & 17.8 & 6.11 & 61 \\
\hline 7 & córrego do Limoeiro & 506172 & 7611146 & 3 & 967 & 2 & 0.5 & 6.65 & 18 & 6 & 96 \\
\hline 8 & rio Ingaí - P4 & 507056 & 7613168 & 6 & 932 & 20 & $>2$ & 6.67 & 19.6 & 5.9 & 70 \\
\hline 9 & ribeirão do Lavarejo & 511288 & 7607953 & 4 & 1067 & 6 & 1 & 6.35 & 16.6 & 6.77 & 91 \\
\hline 10 & córrego da Bela Cruz & 514427 & 7607983 & 4 & 984 & 3 & 2 & 6.32 & 16.1 & 5.74 & 89 \\
\hline 11 & rio Ingaí - P5 & 523315 & 7598696 & 6 & 999 & 10 & $>2$ & 6.15 & 18 & 4.45 & 53 \\
\hline 12 & córrego Traituba & 528313 & 7607703 & 4 & 1015 & 4 & 0.5 & 6.58 & 14.5 & 6.21 & 99 \\
\hline 13 & córrego do Retiro & 526365 & 7617527 & 3 & 965 & 12 & 0.6 & 6.6 & 17.4 & 5.27 & 67 \\
\hline 14 & rio Capivari - P1 & 530311 & 7624126 & 6 & 937 & 8 & 3 & 6.33 & 16.2 & 4.54 & 80 \\
\hline 16 & córrego da Bexiga & 537750 & 7625638 & 3 & 1132 & 5 & 1.5 & 7.5 & 13.9 & 4.7 & 83 \\
\hline 17 & cachoeira do Padre & 529747 & 7625644 & 6 & 927 & 15 & 3 & 8.4 & 13.6 & 5.4 & 72 \\
\hline 18 & córrego do Moleque & 538776 & 7612792 & 4 & 1214 & 15 & $>2$ & 7.4 & 13.5 & 2.4 & 73 \\
\hline 19 & córrego da Caciana & 539528 & 7622296 & 3 & 1053 & 2 & 0.5 & 7.8 & 14 & 6.2 & 66 \\
\hline 20 & ribeirão dos Ferreira & 530799 & 7621079 & 5 & 982 & 5 & 1.3 & 8.5 & 13.6 & 6.3 & 78 \\
\hline 21 & córrego Grão Mogol & 532094 & 7616800 & 3 & 1013 & 2 & 0.5 & 8.1 & 13.7 & 5.6 & 87 \\
\hline 22 & rio Capivari - P2 & 537511 & 7617296 & 4 & 1002 & 15 & 1.5 & 7.7 & 15.1 & 6.7 & 80 \\
\hline 23 & Fazenda da Barra & 512119 & 7639509 & 3 & 935 & 1 & 0.3 & 7 & 16.5 & 6.9 & 72 \\
\hline 24 & Fazenda Funil & 519718 & 7628149 & 6 & 881 & 10 & 4 & 8.7 & 20.1 & 7.8 & 69 \\
\hline 26 & ribeirão da Fortaleza & 517339 & 7628929 & 3 & 895 & 3 & 2 & 9.1 & 16.6 & 7 & 78 \\
\hline 27 & rio Ingaí - P6 & 509003 & 7633096 & 3 & 906 & - & $>2$ & 9 & 22 & 6.4 & - \\
\hline 28 & ribeirão da Primavera & 509431 & 7631576 & 4 & 908 & 2 & 1 & 8.5 & 17.1 & 6 & 76 \\
\hline 29 & rio Ingaí - P7 & 510834 & 7637830 & 6 & 883 & 20 & $>2$ & 8.8 & 20.6 & 8.5 & 58 \\
\hline 30 & ribeirão Malha Feijão & 508961 & 7638180 & 4 & 880 & 2.5 & 1.2 & 9.1 & 15.3 & 8.1 & 87 \\
\hline 31 & córrego do Quilombo & 507516 & 7635458 & 4 & 895 & 2 & 0.5 & 9.1 & 16.4 & 6 & 74 \\
\hline 33 & Fazenda Tapera & 509354 & 7635900 & 4 & 900 & 2 & 1.7 & 8.4 & 16.7 & 5.9 & 70 \\
\hline 34 & córrego Escuro & 520866 & 7622623 & 3 & 962 & 1.5 & 0.9 & 8.7 & 15.8 & 5.8 & 76 \\
\hline 35 & córrego das Pedras & 525840 & 7622564 & 4 & 942 & 3 & 0.7 & 8.9 & 16.9 & 6.5 & 79 \\
\hline 36 & rio Íngai - P8 & 519409 & 7612753 & 6 & 958 & 13 & 2 & 9 & 20.2 & 6.6 & 63 \\
\hline 37 & rio Íngai - P9 & 518014 & 7612517 & 6 & 974 & 15 & 2 & 8.8 & 20.1 & 6.5 & 56 \\
\hline 38 & córrego Mata Grande & 523563 & 7614176 & 3 & 1005 & 1.5 & 0.5 & 8.8 & 15.6 & 5.9 & 84 \\
\hline 39 & córrego dos Cabritos & 528888 & 7617533 & 4 & 972 & 1.5 & 0.7 & 8.6 & 18.3 & 6.4 & 74 \\
\hline 40 & córrego da Lavrinha & 515870 & 7608807 & 4 & 984 & 3 & 0.8 & 9 & 22.3 & 6.5 & 70 \\
\hline 41 & córrego da Aroeira & 518740 & 7607912 & 4 & 993 & 1.7 & 0.6 & 8.5 & 18.9 & 7.6 & 87 \\
\hline 42 & rio Ingaí - P10 & 522634 & 7607694 & 6 & 996 & 25 & $>2$ & 8.6 & 22.1 & 7.1 & 68 \\
\hline 43 & ribeirão da Boa Vista & 519152 & 7601983 & 4 & 996 & 2.5 & 0.7 & 8.9 & 20.2 & 6.6 & 68 \\
\hline 45 & ribeirão Favacho & 527435 & 7603236 & 4 & 1032 & 2 & 1 & 7.9 & 17.8 & 5.4 & 81 \\
\hline 46 & córrego da Divisa & 517850 & 7625085 & 3 & 988 & 2 & 0.7 & 8.6 & 18.4 & 5.2 & 84 \\
\hline 47 & rio Capivari - P3 & 514613 & 7636755 & 6 & 877 & 18 & 1.7 & 9 & 22.4 & 7 & 70 \\
\hline 48 & rio Carrancas - P1 & 535710 & 7625197 & 3 & 1038 & 6 & 1.5 & 7.3 & 18.6 & 6 & 83 \\
\hline 49 & rio Carrancas - P2 & 534464 & 7625185 & 2 & 1032 & 3 & 1.5 & 7.3 & 18.5 & 5.6 & 78 \\
\hline 50 & Fazenda das Cobras & 536274 & 7621102 & 5 & 954 & 10 & 1 & 8 & 19.3 & 5.9 & 53 \\
\hline
\end{tabular}

A total of 1,308 individuals of 41 species were captured (Table 2). Two species are considered allochtonous to the study area. Despite the stabilization of the species accumulation curve (Fig. 3), richness estimators Jackknife 1 and Chao 1 point to the possible occurrence of a much larger number of species: $55.7(\mathrm{SD}=5.29)$ and $50.5(\mathrm{SD}=5.92)$ respectively.

Degree of conservation, altitude and width were the parameters that best explained species richness in the sampled watercourses $\left(p<0.001 ; r^{2}=0.41\right)$. Given the negative relationship between altitude and width, the influence of these factors may be related to the altitudinal distribution of species in the region. Only three species (Pareiorhaphis sp., Trichomycterus brasiliensis and Astyanax aff. scabripinnis) occurred in altitudes above 1,070 meters while only eight occurred above 1,020 meters (Fig. 4).
The CCA analysis also revealed a significant relationship between the most abundant fish species and habitat variables $(p=0.002)$. The two axes in CCA accounted for $62.7 \%$ of the variation in species abundance and habitat variables (Fig. 5; Table 3). CCA 1 accounted for $42.6 \%$ of the variance and was determined by altitude, conservation status and river width, smaller watercourses in higher altitudes were found to be in better conservation state. In the second axis dissolved oxygen and temperature predominated but their explained variances were low (20.1\%). Trichomycterus spp., A. aff. scabripinnis and Pareiorhina carrancas, for instance, can be regarded as being typical of narrower, higher and well-preserved environments, while Brycon nattereri, Salminus hilarii and Leporinus paranensis are found in larger and well-oxygenated rivers. 


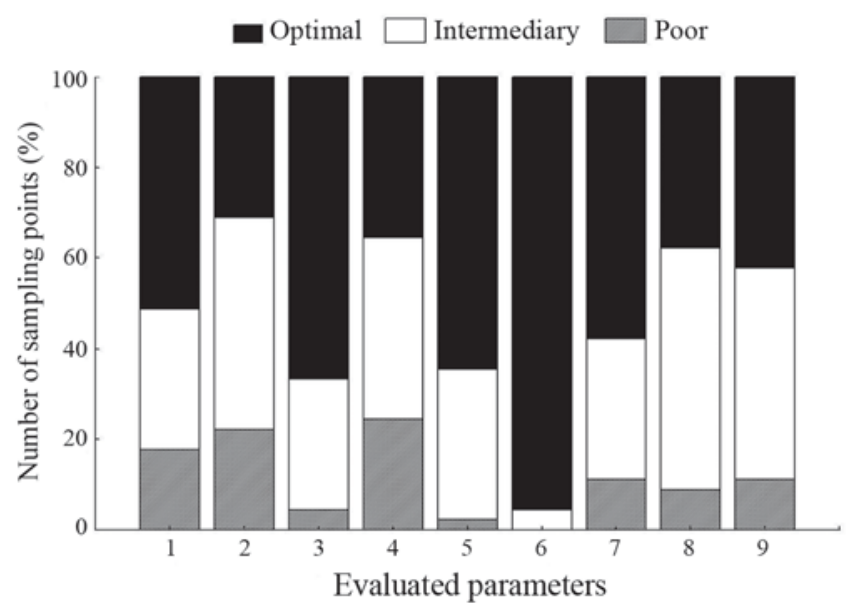

Fig. 2. Relative number of sampling points in different degrees of conservation for each evaluated parameter (1 - Available cover; 2 - Embeddedness; 3 - Velocity/depth regime; 4 Sediment deposition; 5 - Channel flow status; 6 - Channel alteration; 7 - Bank stability; 8 - Vegetative protection; 9 Riparian vegetative zone width).

Considering the recently proposed boundaries for potential conservation units in the region (Fig. 1), only 14 or 22 out of 41 species would be found in the State Park and Environmental Protection Area (EPA), respectively.

\section{Discussion}

This study revealed a considerable increase in the number of known species in the drainage basin of upper rio Grande. An amount of 39 species were known for the rio Grande (CEMIG, 2000), and 18 species for the Itutinga reservoir (Alves et al., 1998). With the addition of another 41 species from this study, the Minas Gerais portion of the basin has now 72 recorded species. If we include the tributaries of rio Grande draining the São Paulo State (Castro et al., 2004), the species richness reaches at least 105 species. We should note that studies are yet scarce on smaller watercourses of the basin, especially in the Minas Gerais portion, suggesting that richness is possibly much higher.

Although only two exotic species were recorded, this number is compatible with the proportion of these species in upper rio Paraná basin in Minas Gerais, which is about 10\% (Alves et al., 2007). Originally from South America and Africa respectively, Poecilia reticulata and Tilapia rendalli are widely disseminated and found in virtually every drainage basin of Minas Gerais State (Alves et al., 2007).

The progressive increase in number of fish species from headwater to downstream is well known (Horwitz, 1978), and richness has been predicted by altitude and stream order measurements (Platts, 1979; Beecher et al., 1988). Species addition has been related to the gradual increasing on living space, habitat diversity and environmental stability downstream (Horwitz, 1978). In the rio Capivari basin, the altitudinal effect on fish richness was evident, and creates a
Table 2. Recorded species in the region of upper Capivari River (*exotic species; SP - proposed State Park, EPA proposed Environmental Protection Area; O - outside the proposed conservation areas).

\begin{tabular}{|c|c|c|c|}
\hline Species / Occurrence & SP & EPA & $\mathrm{O}$ \\
\hline \multicolumn{4}{|l|}{ Order Characiformes } \\
\hline \multicolumn{4}{|l|}{ Anostomidae } \\
\hline Leporellus vittatus (Valenciennes, 1850) & & $\mathrm{x}$ & $\mathrm{x}$ \\
\hline Leporinus amblyrhynchus Garavello \& Britski, 1987 & & & $\mathrm{x}$ \\
\hline Leporinus paranensis Garavello \& Britski, 1987 & & & $\mathrm{x}$ \\
\hline \multicolumn{4}{|l|}{ Leporinus sp. } \\
\hline \multicolumn{4}{|l|}{ Characidae } \\
\hline Astyanax altiparanae Garutti \& Britski, 2000 & & $\mathrm{x}$ & $\mathrm{x}$ \\
\hline Astyanax fasciatus (Cuvier, 1819) & $\mathrm{x}$ & $\mathrm{x}$ & $\mathrm{x}$ \\
\hline Astyanax aff. scabripinnis (Jenyns, 1842) & $\mathrm{x}$ & $\mathrm{x}$ & $\mathrm{x}$ \\
\hline Brycon nattereri Günther, 1864 & & & $\mathrm{x}$ \\
\hline Odontostilbe sp. & & & $\mathrm{x}$ \\
\hline Piabina argentea Reinhardt, 1867 & & & $\mathrm{x}$ \\
\hline Salminus hilarii Valenciennes, 1850 & & & $\mathrm{x}$ \\
\hline Serrapinnus sp. & & $\mathrm{x}$ & \\
\hline \multicolumn{4}{|l|}{ Crenuchidae } \\
\hline Characidium gomesi Travassos, 1956 & $\mathrm{x}$ & $\mathrm{x}$ & \\
\hline Characidium zebra Eigenmann, 1909 & & & $\mathrm{x}$ \\
\hline Characidium sp. & & & $\mathrm{x}$ \\
\hline Curimatidae & & & $\mathrm{x}$ \\
\hline Steindachnerina insculpta (Fernández-Yépez, 1948) & & $\mathrm{x}$ & \\
\hline \multicolumn{4}{|l|}{ Herythrinidae } \\
\hline Hoplias malabaricus (Bloch, 1794) & $\mathrm{x}$ & & \\
\hline \multicolumn{4}{|l|}{ Parodontidae } \\
\hline Apareiodon affinis (Steindachner, 1879) & & & $\mathrm{x}$ \\
\hline Apareiodon ibitiensis Amaral Campos, 1944 & & & $\mathrm{x}$ \\
\hline Parodon nasus Kner, 1859 & $\mathrm{x}$ & & \\
\hline \multicolumn{4}{|l|}{ Order Cyprinodontiformes } \\
\hline \multicolumn{4}{|l|}{ Poeciliidae } \\
\hline Phalloceros harpagos Lucinda, 2008 & & & $\mathrm{x}$ \\
\hline Poecilia reticulata Peters, 1859* & & $\mathrm{x}$ & \\
\hline \multicolumn{4}{|l|}{ Order Gymnotiformes } \\
\hline \multicolumn{4}{|l|}{ Sternopygidae } \\
\hline Eigenmannia virescens (Valenciennes, 1836) & & & $\mathrm{x}$ \\
\hline \multicolumn{4}{|l|}{ Order Perciformes } \\
\hline \multicolumn{4}{|l|}{ Cichlidae } \\
\hline Cichlasoma aff. facetum (Jenyns, 1842) & $\mathrm{x}$ & & $\mathrm{x}$ \\
\hline Tilapia rendalli (Boulenger, 1897)* & & & $\mathrm{x}$ \\
\hline Geophagus brasiliensis (Quoy \& Gaimard, 1824) & $\mathrm{x}$ & & $\mathrm{x}$ \\
\hline \multicolumn{4}{|l|}{ Order Siluriformes } \\
\hline \multicolumn{4}{|l|}{ Heptapteridae } \\
\hline Cetopsorhamdia iheringi Schubart \& Gomes, 1959 & & $\mathrm{x}$ & $\mathrm{x}$ \\
\hline \multicolumn{3}{|l|}{ Heptapterus sp. } & $\mathrm{x}$ \\
\hline Rhamdia quelen (Quoy \& Gaimard, 1824) & & & $\mathrm{x}$ \\
\hline \multicolumn{4}{|l|}{ Loricariidae } \\
\hline Hypostomus sp. 1 & $\mathrm{x}$ & $\mathrm{x}$ & $\mathrm{x}$ \\
\hline Hypostomus sp. 2 & $\mathrm{x}$ & $\mathrm{x}$ & $\mathrm{x}$ \\
\hline Hypostomus sp. 3 & & & $\mathrm{x}$ \\
\hline Neoplecostomus paranensis Langeani, 1990 & $\mathrm{x}$ & $\mathrm{x}$ & $\mathrm{x}$ \\
\hline Neoplecostomus sp. 2 & & $\mathrm{x}$ & \\
\hline Pareiorhaphis sp. & & $\mathrm{x}$ & $\mathrm{x}$ \\
\hline Pareiorhina carrancas Bockmann \& Ribeiro, 2003 & $\mathrm{x}$ & $\mathrm{x}$ & $\mathrm{x}$ \\
\hline Pimelodidae & & & \\
\hline Iheringichthys labrosus (Lütken, 1874) & & & $\mathrm{x}$ \\
\hline Pimelodus heraldoi Azpelicueta, 2001 & & & $\mathrm{x}$ \\
\hline Pimelodus maculatus Lacepède, 1803 & & & $\mathrm{x}$ \\
\hline Trichomycteridae & & & \\
\hline Trichomycterus brasiliensis Lütken, 1874 & $\mathrm{x}$ & $\mathrm{x}$ & $\mathrm{x}$ \\
\hline Trichomycterus aff. itatiayae Miranda Ribeiro, 1906 & $\mathrm{x}$ & $\mathrm{x}$ & $\mathrm{x}$ \\
\hline
\end{tabular}

challenger concerning the fish fauna conservation. Larger rivers, which shelter more complex fish communities, are located in low altitude areas which are less preserved. 


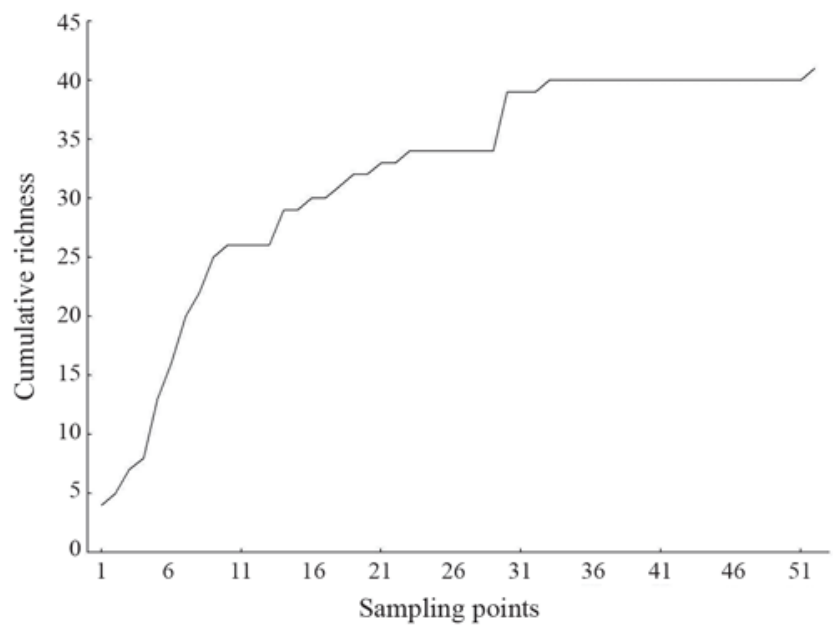

Fig. 3. Species accumulation curve for sampling points in upper rio Capivari basin.

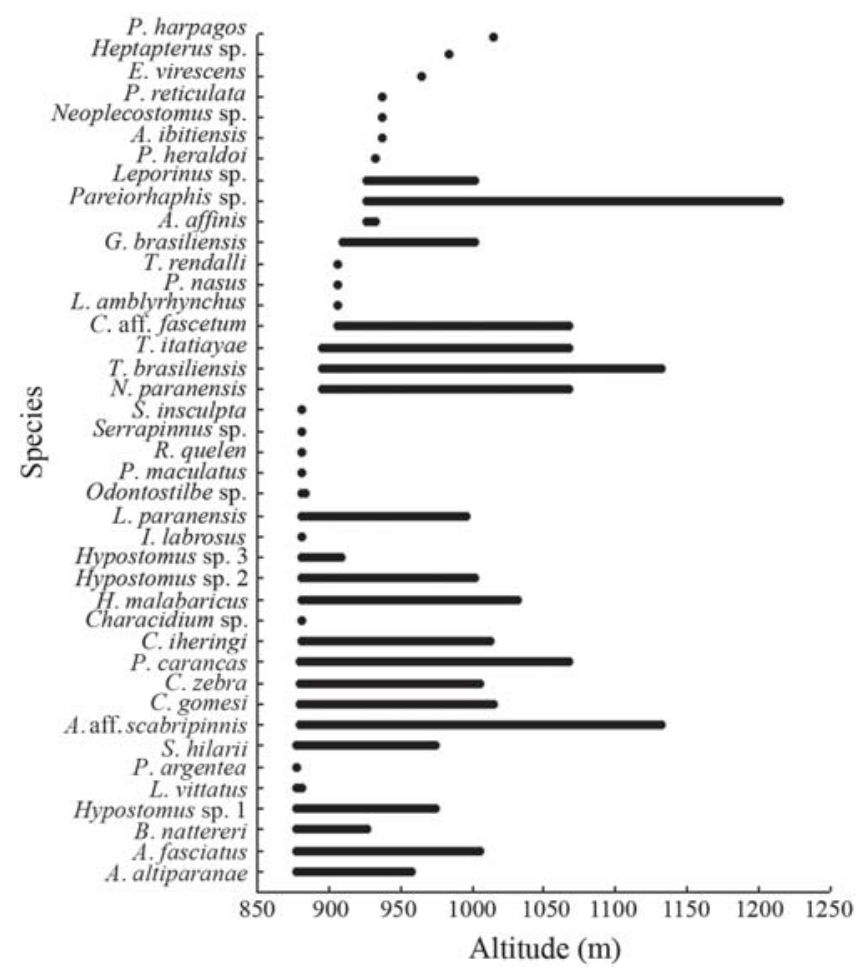

Fig. 4. Altitudinal distribution of sampled species in the region of upper rio Capivari basin.

The consequences of this pattern can be illustrated by the pirapitinga (Brycon nattereri) distribution. Among the captured species, it is the only one considered endangered (Machado et al., 2005). The upper Capivari region has been used as a source of this species in order for the development of breeding stock in farming stations. If we consider the boundaries of the proposed conservation unit, two sampled occurrence points of this species are left out (stations 24 and 29) while the other two lie in bordering areas of the park (stations 47 and 17). This occurrence pattern can be related to its environmental preferences: larger and well-oxygenated

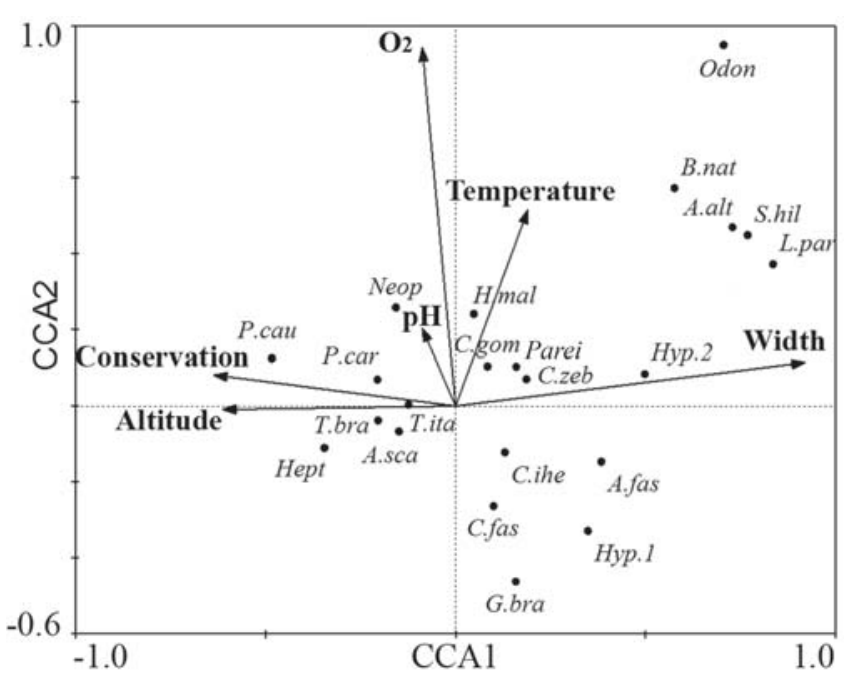

Fig. 5. Pattern of fish species distribution among environmental variables, based on canonical correspondence analysis ordination (A. alt = Astyanax altiparanae; $A$. fas = Astyanax fasciatus; A. sca = Astyanax aff. scabripinnis; $B$. nat = Brycon nattereri; $C$. fac $=$ Cichlasoma aff. facetum; $C$. gom = Characidium gomesi; . zebra = Characidium zebra; C. ihe = Cetopsorhamdia iheringi; G. bra = Geophagus brasiliensis; Hept = Heptapterus sp.; H. mal = Hoplias malabaricus; Neop = Neoplecostomus paranensis; Hyp. $1=$ Hypostomus sp. 1; Hyp. 2 = Hypostomus sp. 2; L. par = Leporinus paranensis; Odon = Odontostilbe sp.; Parei = Pareiorhaphis sp.; P. car = Pareiorhina carrancas; $P$. har $=$ Phalloceros harpagos; S. hil = Salminus hilarii; $T$. bra = Trichomycterus brasiliensis; T. ita = Trichomycterus itatiayae).

rivers. The conservation status of the species could be also explained by this aspect, since well preserved rivers are mostly small sized ones, and located in the headwaters.

With recognition of the global biodiversity crisis in the 1980's (Wilson, 1988), many efforts were initiated to prioritize areas for conservation action on the basis of total species richness or the number of endemic species. This approach, analysis of geographic patterns assuming a particular taxonomic authority list to be representative, leads investigators to focus attention on species' distributions without concern for geographic variation, systematic problems, or species limits (Peterson \& Navarro-Sigüenza, 1999). In addition, identification of conservation areas ideally requires exhaustive knowledge of species and ecosystem diversity and distribution, but detailed inventories in the field are severely constrained by limited resources and time (Menon et al., 2001). For this reason, the analysis of threats to biodiversity is frequently based on threatened vegetation categories, presenting high integrity areas susceptible to deforestation and not protected by law restrictions, have been the most selected areas for conservation.

Freshwater fish are probably the world's most threatened group of vertebrates after amphibians (Bruton, 1995), and in North America the extinction rate of freshwater animals is 
Table 3. Results of Canonical Correspondence Analyses (CCA) of fish abundance and environmental variable.

\begin{tabular}{lcccc}
\hline \multicolumn{1}{c}{ Variable / Axis } & 1 & 2 & 3 & 4 \\
\hline Altitude & -0.53 & -0.01 & 0.28 & 0.38 \\
Width & 0.80 & 0.08 & 0.28 & 0.01 \\
pH & -0.08 & 0.14 & -0.55 & 0.04 \\
Temperature & 0.17 & 0.36 & -0.17 & 0.14 \\
Dissolved oxygen & -0.08 & 0.65 & -0.19 & -0.19 \\
Conservation & -0.55 & 0.06 & 0.43 & -0.64 \\
\hline \multicolumn{1}{c}{ Axis } & & & & \\
\hline Eigenvalues (c.481 & 0.226 & 0.214 & 0.101 \\
Percentual cumulative variation & 42.6 & 20.1 & 19.0 & 8.9 \\
Species / Variable correlation & 0.872 & 0.692 & 0.763 & 0.557 \\
\hline
\end{tabular}

estimated to be three times higher than that of marine mammals and almost five times higher than that of terrestrial animals (Ricciardi et al., 1999). Disturbances are to a large extent related to engineering works, domestic and industrial sewage, land use practices as well as fishing and storage (Maitland, 1995), while habitat destruction and introduction of exotic species are cited as the primary causes of extinction of several fish species in North America (Miller et al., 1989). Despite the consequences of this scenario, the preservation of fish communities has been receiving less attention than other vertebrates (Maitland, 1985).

The creation of protected areas is potentially a partial solution, as it could prevent the destruction of habitats and regulate predatory fishing practices. However few of them have been created specifically for aquatic environments. Examples worldwide include alluvial floodplains, deltas and lakes (Saunders et al., 2002). In Brazil, the best known example is the environmental protection area of upper rio Paraná $\left(526,000 \mathrm{~km}^{2}\right)$, capable of embracing most local fish species (Agostinho et al., 2005).

An urgent need to create more conservation units specifically intended for fish protection has been identified by several authors (Keith, 2000; Saunders et al., 2002). In practice, studies indicate that the central areas of national parks have been ineffective tools for fish conservation, because most of them are located in mountainous areas of high altitude, where there are only headwaters streams and threatened species are not found (Keith, 2000). These areas are typically selected for conservation based on vegetation remains.

In Southeastern Brazil, where most threats to fish fauna are concentrated, conservation units also follow the same pattern, as they typically comprise hilltop areas and therefore exclude a large number of species that are not present in this type of environment. Within the boundaries of Serra do Cipó National Park, for instance, only 16 species are found out of 48 species inventoried in the region (Vieira et al., 2005), while in rio Cipó only 10 out of 72 species recorded in that River (Alves \& Pompeu, 2005) were captured. Low species richness was also found in Serra do Mar State Park (Gomiero \& Fraga, 2006) and in the das Neblinas Park (Serra et al., 2007).

Same pattern would be observed considering the original area proposed for the State Park in the Capivari basin region, where only $37 \%$ of the regional fish richness would be found. However, these areas play a partial role in the maintenance of aquatic biodiversity environments, since the maintenance of water quality in small headwater streams is a key point to secure water quality in larger rivers.

Seeing the great number of fish species registered, including endangered ones, state that as has been established by the atlas of priority areas in Minas Gerais State (Drummond, et al., 2005), we can affirm that the upper Capivari region remains key to the conservation of the ichthyofauna of upper rio Grande. However, if the establishment of conservation units in the region will be based only on the presence of vegetation remains, a small fraction of the local fish community would be protected. In such context, the conservation of other fluvial landscapes, such as specific stretches of rivers, floodplains, etc, is critical, as well as the actual implementation of the diverse regulations, public policies, and mechanisms for river protection and restoration.

\section{Acknowledgements}

We are grateful to Fundação de Amparo à Pesquisa do Estado de Minas Gerais (FAPEMIG) for the financial support, the anonymous referees for the suggestion to the manuscript, Ludmilla Zambald for the map elaboration and the Ecology Sector of Federal University of Lavras for the logistics support.

\section{Literature Cited}

Agostinho, A. A., S. M. Thomaz \& L. C. Gomes. 2005. Conservação da biodiversidade em águas continentais do Brasil. Megadiversidade, 1(1): 70-78.

Allan, J. D. \& A. S. Flecker. 1993. Biodiversity conservation in running waters. BioScience, 43(1): 32-43.

Alves, C. B. M. \& P. S. Pompeu. 2005. Historical changes in the Rio das Velhas fish fauna - Brazil. Pp. 587-602. In: Rinne, J. N., R. M. Hughes \& B. Calamusso (Eds.). Historical changes in large river fish assemblages of the Americas. American Fisheries Society, Symposium 45, Bethesda, Maryland, 612p.

Alves, C. B. M., A. L. Godinho, H. P. Godinho \& V. C. Torquato. 1998. A Ictiofauna da Repressa de Itutinga, Rio Grande (Minas Gerais - Brasil). Revista Brasileira de Biologia, 58(1): 121-129.

Alves, C. B. M., F. Vieira, A. L. Magalhães \& M. F. G. Brito. 2007. Impacts of non-native fish species in Minas Gerais, Brazil: present situation and prospects. Pp. 291-314. In: Bert, T. M. (Org.). Ecological and Genetic Implications of Aquaculture Activities. 1a. ed. Dordrecht, The Netherlands, Springer, 539p.

Bain, M. B. \& N. J. Stevenson. 1999. Aquatic habitat assessment: common methods. Bethesda, Maryland, American Fisheries Society, 224p.

Barbour, M. T., J. Gerritsen, B. D. Snyder \& J. B. Stribling. 1999. Rapid Bioassessment Protocols for Use in Streams and Wadeable Rivers: Periphyton, Benthic Macroinvertebrates and Fish. Washington, DC, Environmental Protection Agency, 339p.

Beecheer, H. A., E. Dott \& R. Fernau. 1988. Fish species richness and stream order in Washington State streams. Environmental Biology of Fishes, 22(3): 193-209. 
Bruton, M. N. 1995. Have fishes had their chips? The dilemma of threatened fishes. Environmental Biology of Fishes, 43(1): 1-27.

Castro, R. M. C., L. Casatti, H. F. Santos, A. L. A. Melo, L. S. F. Martins, K. M. Ferreira, F. Z. Gibran, R. C. Benine, M. Carvalho, A. C. Ribeiro, T. X. Abreu, F. A. Bockmann, G. Z. Pelição, R. Stopiglia \& F. Langeani. 2004. Estrutura e composição da ictiofauna de riachos da bacia do rio Grande no estado de São Paulo, sudeste do Brasil. Biota Neotropica, 4(1): 1-39.

CEMIG. 2000. Guia Ilustrado da Bacia do Rio Grande. Belo Horizonte: CEMIG/CETEC, 2000. 144p.

CETEC. 1983. Diagnóstico Ambiental do Estado de Minas Gerais. Fundação Centro Tecnológico de Minas Gerais/CETEC. Série de Publicações Técnicas/SPT-010, 158p.

Chow, V. T., D. R. Maidment \& L. W. Mays. 1988. Applied Hydrology. New York, Mcgraw-Hill Book Company, 572p.

Conservation International do Brasil. 2000a. Planejando paisagens sustentáveis: a Mata Atlântica Brasileira. Conservation International \& Instituto de Estudos Sócio-Ambientais do Sul da Bahia, 28p.

Conservation International do Brasil. 2000b. Avaliação de ações prioritárias para a conservação da biodiversidade da Mata Atlântica e Campos Sulinos. Brasília, Ministério do Meio Ambiente, 40p.

Drummond, G. M., C. S. Martins, A. B. M. Machado, F. A. Sebaio \& Y. Antonini (Orgs.). 2005. Biodiversidade em Minas Gerais: um Atlas para sua conservação. Belo Horizonte, Fundação Biodiversitas, 222p.

Colwell, R. K. 1997. EstimateS: Statistical estimation of species richness and shared species from samples. Version 8.2. User's Guide and application published at: http://viceroy.eeb.uconn.edu/ estimates.

Gomiero, L. M. \& F. M. Braga. 2006. Ichthyofauna diversity in a protected area in the state of São Paulo, southeastern Brazil. Brazilian Journal of Biology, 66(1a): 75-83.

Horwits, R. J. 1978. Temporal variability patterns and the distributional patterns of stream fishes. Ecological Monographs, 48(3): 307-321.

Keith, P. 2000. The part played by protected areas in the conservation of threatened French freshwater fish. Biological Conservation 92(3): 265-273.

Machado, A. B. M., C. S. Martins \& G. M. Drummond. 2005. Lista da fauna brasileira ameaçada de extinção: incluindo as espécies quase ameaçadas e deficientes em dados. Belo Horizonte, Fundação Biodiversitas, 160p.

Maitland, P. S. 1985. Criteria for the selection of important sites for freshwater fish in the British Isles. Biological Conservation, 31(4): 335-353.

McAllister, D. E., A. L. Hamilton \& B. Harvey. 1997. Global freshwater biodiversity: striving for the integrity of freshwater ecosystems. Sea Wind, 11(3): 1-142.

Menon, S., R. Gil Pontius Jr, J. Rose, M. L. Khan \& K. S. Bawa. 2001. Identifying Conservation-Priority Areas in the Tropics: a Land-Use Change Modeling Approach. Conservation Biology, 15(2): 501-512.

Miller, R. R., J. D. Williams \& J. E. Williams. 1989. Extinctions of North American fishes during the past century. Fisheries, 14(6): 22-38.

Mittermeier, R. A., G. A. B. Fonseca, A. B. Hylands \& K. Brandon. 2005. Uma breve história da conservação da biodiversidade no Brasil. Megadiversidade, 1(1): 14-21.

Peterson, T. \& A. G. Navarro-Sigüenza. 1999. Alternate Species Concepts as Bases for Determining Priority Conservation Areas. Conservation Biology, 13(2): 427-431.
Petts, G. E. 1989. Perspectives for ecological management of regulated rivers. Pp. 3-24. In: Gore, J. A. \& G. E. Petts (Eds.). Alternatives in regulated river management. Florida, CRC Press, 344p.

Platts, W. S. 1979. Relationships among stream order, fish populations, and aquatic geomorphology in an Idaho River Drainage. Fisheries, 4(2): 5-9.

Pompeu, P. S., C. B. M. Alves \& M. Callisto. 2005. The effects of urbanization on biodiversity and water quality in the Rio das Velhas basin, Brazil. Pp. 11-22. In: Brown, L. R., R. M. Hughes, R. Gray \& M. R. Meador (Eds.). Effects of urbanization on stream ecosystems. American Fisheries Society, Symposium 47, Bethesda, Maryland, 423p.

Queiroz, R., A. G. Souza, P. Santana, F. Z. Antunes \& M. Fontes. 1980. Zoneamento agroclimático do Estado de Minas Gerais. Viçosa, UFV, 114p.

Ricciardi, A., R. J. Neves \& J. B. Rasmussen. 1999. Extinction rates of North American freshwater fauna. Conservation Biology, 13: $1-3$.

Sale, M. J. 1985. Aquatic ecosystem response to flow modification: an overview of the issues. Pp. 25-31. In: Olson, F. W. (Ed.). Proceedings of the Symposium on small hydropower and fisheries. Bethesda, American Fisheries Society, 497p.

Saunders, D. L., J. J. Meeuwig \& A. C. J. Vincent. 2002. Freshwater protected areas: strategies for conservation. Conservation Biology, 16(1): 30-41.

Serra, J. P., F. R. Carvalho \& F. Langeani. 2007. Ichthyofauna of the Itatinga river in the Parque das Neblinas, Bertioga, São Paulo: Composition and Biogeography. Biota Neotropica, 7(1): 1-6.

Shepp, D. L. \& J. D. Cummins. 1997. Restoration in a urban watershed: Anacostia River of Maryland and the district of Columbia. In: Willians, J. E., C. A. Wood \& M. P. Dombeck (Eds.). Watershed restoration: principles and practices. Bethesda, Maryland, American Fisheries Society, 559p.

Strahler, A. N. 1964. Quantitative geomorphology of drainage basins and channel networks. Pp. 39-76. In: Chow, V. T. (Ed.). Handbook of applied hydrology. New York, McGraw-Hill, 572p.

Vieira, F., G. B. Santos \& C. B. M. Alves. 2005. A ictiofauna do Parque Nacional da Serra do Cipó e áreas adjacentes. Lundiana, 6: 77-87.

Vieira, V. T. \& S. B. Cunha. 2001. Mudanças na rede de drenagem urbana de Terezópolis (Rio de Janeiro). Pp. 111-145. In: Guerra, A. J. T. \& S. B. Cunha (Eds.). Impactos ambientais urbanos no Brasil. Rio de Janeiro, Bertrand Brasil, 416p.

Wilson, E. O. 1988. Biodiversity. Washington D.C., National Academy Press, 521p.

Zambaldi, L. P., J. N. C. Louzada, L. M. T. Carvalho \& L. R. S. Scolforo. (in press). Análise da vulnerabilidade natural e seleção de áreas para implantação de Unidades de Conservação na microregião da serra de Carrancas, MG. Cerne.

Accepted September 24, 2009 Published December 18, 2009 